\title{
KOMUNIKASI ORANG TUA-ANAK DALAM AL-QURAN (Studi terhadap QS. Ash-Shaffat ayat 100-102)
}

\author{
Siti Zainab*1
}

\begin{abstract}
Abstrak
Tulisan ini bertujuan untuk mengungkap bagaimana komunikasi orangtua-anak dalam perspektif al-Quran khususnya pada Q. S., ash shaffat ayat 100-102.

Penelitian ini murni kepustakaan dengan menggunakan pendekatan tafsir. Teknik yang digunakan adalah dengan seleksi sumber dan analisis isi. Data primer adalah alQuran al-karim dan kitab-kitab tafsir, sedangkan data sekunder adalah buku-buku yang berkaitan dengan Ilmu Komunikasi. Data dianalisis dengan menggunakan tafsir tahlili .

Hasil penelitian menunjukkan, Pertama: Kandungan Q. s., ash shaffat ayat 100-102 mengemukakan betapa pentingnya sebuah do'a dipanjatkan secara sungguh-sungguh oleh orangtua agar diberi anak yang shaleh; ketika dianegerahi seorang anak hendaklah dididik dengan baik agar tumbuh menjadi anak yang shaleh; ketika mendidik anak tentunya banyak terdapat cobaan, masalah dan hambatan, selain penanaman agama sejak dini kepada anak, cara lainnya dilakukan dengan menjalin komunikasi yang baik antara orangtua dan anak. Kedua: Komunikasi orangtua-anak yang dibangun antara nabi Ibrahim a.s. dengan Nabi Ismail a.s.pada Q. s., ash-shaffat ayat 100-102 adalah : membangun kebersamaan dan kepercayaan; menjalin komunikasi yang baik melalui cara saling terbuka, melakukan dialog/diskusi dengan rasa saling menghargai dan menghormati; dapat berempati dan saling mendukung sehingga adanya kesamaan visi dalam melihat persoalan yang pada akhirnya tercipta komunikasi yang efektif. Kesamaan visi tersebut bersumber dari pemahaman agama yang benar dan sama -sama berusaha melaksanakan dan mengikhlashkannya. Komunikasi yang terjalin baik antara orangtua dan anak karena keduanya (baik sebagai komunikator maupun komunikan) memiliki karakter yang kuat (iman yang kuat, ilmu yang tinggi serta perilaku yang baik). Selain itu dalam berkomunikasi dilakukan dengan pemilihan bahasa/ kata yang baik dan menerapkan teknik komunikasi yang tepat dan benar.
\end{abstract}

Kata kunci : Komunikasi Orangtua-anak, Q.S., ash Shaffat ayat 100-102

\section{PENDAHULUAN}

Komunikasi adalah sesuatu yang penting dalam kehidupan manusia. Kegiatan ini dilakukan secara terus menerus dilakukan oleh manusia, mulai dari bangun tidur hingga tidur kembali. Dalam setiap harinya kegiatan manusia berkomunikasi 80 persen. Komunikasi menjadi sangat penting terutama dalam keluarga, baik itu antara suami dengan istri atau istri dengan suami maupun dengan anak sekalipun.

Komunikasi antara orang tua dan anak merupakan salah satu kunci interaksi dua arah antara orang tua-anak dan sebaliknya. Kebanyakan munculnya konflik diantara orang tua dan anak adalah akibat kurangnya intensitas komunikasi diantara kedua belah pihak, dimana yang menjadi pemicunya biasanya ada di pihak orang tua yang mungkin karena kesibukannya sehingga jarang berkomunikasi dengan anaknya.

\footnotetext{
* Penulis adalah dosen tetap pada Jurusan Dakwah dan Komunkasi Islam/KPI Institut Agama Islam Negeri (IAIN) Palangka Raya. Ia memperoleh gelar Magister Agama (MA) konsentrasi Dakwah dan Komunikasi di UIN Syahid Jakarta tahun 2005.
} 
Setiap anak terlahir untuk menjadi dirinya sendiri dengan segudang fitrah yang telah disiapkan Tuhan untuknya. Orangtua-lah yang akan memperlakukan fitrah itu dengan baik dan terarah pada kebenaran hidup atau tidak. Tidak seorang pun anak kecil yang memiliki otak kriminal pada saat usia mereka di bawah usia tujuh tahun. Karena mereka ibaratnya sebuah kertas yang dapat ditulis ataupun dilukis apa saja. Dengan warna sesuka hati dan dengan seluruh resiko yang akan menanti setelahnya.

Bagi anak, orangtua merupakan figur orang dewasa pertama yang dikenal anak sejak bayi. Selain kedekatan karena faktor biologis, anak biasanya cukup dekat dengan ayah ibunya karena hampir seluruh hidupnya dekat dan dihabiskan bersama orangtuanya. Oleh karena itu, ayah ibu meniliki pengaruh besar terhadap perkembangan anak, termasuk perkembangan karakternya. Berkaitan dengan hal itu, maka orangtua perlu belajar tentang bagaimana mengembangkan karakter yang baik bagi anak-anaknya.

Pada kenyataannya, suatu data penelitian menyatakan bahwa dari $100 \%$ orangtua, yang mampu dan sadar untuk dapat mendidik karakter anak tidak lebih dari $20 \%$ atau 30\%, selebihnya tidak memiliki kapasitas untuk mendidik anak . Banyak kasus kerusakan moral dan perilaku anak yang terjadi disebabkan pengaruh buruk dari pengasuhan orangtua yang tidak patut. Selain itu tantangan kehidupan modern yang ditandai dengan berbagai fenomena, seperti kedua orangtua bekerja, derasnya arus informasi media cetak dan elektronik nyaris tanpa batas ruang dan waktu, dan maraknya pornografi yang tidak terben-dung, diduga juga berpengaruh signifikan terhadap pengembangan karakter anak. Oleh karena itulah ketika suatu keluarga mendapatkan anak, hal utama yang paling penting dipersiapkan adalah bekal penanaman karakter bagi si buah hati. ${ }^{2}$

Secara normatif, Al Qur'an yang diturunkan oleh Allah ke dunia ini untuk dijadikan pedoman bagi seluruh umatNya sudah jelas di dalamnya berisi lengkap tentang semua ilmu pengetahuan termasuk cerita para nabi dan rasul terdahulu untuk dijadikan sebuah pijakan atau teladan bagi umat yang hidup setelahnya.

Dari ayat-ayat Al Qur'an tersebut dapat diambil pelajaran sepertihalnya meneladani kisah Nabi Ibrahim a.s. dalam melakukan interaksi /komunikasi terhadap Nabi Ismail a.s. Nabi Ibrahim yang dijuluki "Khalilullah" (kekasih Allah) memberikan keteladanan yang luar biasa dalam melakukan pendidikan terhadap keluarga dan anak-anaknya. Karena dari kisahkisah beliau dapat kita ambil pelajarannya sampai sekarang. Seperti dituliskan dalam firman Allah dalam surat $\mathrm{Al}$-mumtahanah ayat 4 yang artinya: "Sesungguhnya telah ada suri tauladan yang baik bagimu pada Ibrahim dan orang-orang yang bersama dengan dia" ...(Q.S. AlMumtahanah [60]: 4) ${ }^{3}$

Dari ayat diatas, terlihat bahwa banyak hal yang dapat teladani dari Nabi Ibrahim a.s. dan orang - orang yang bersama dengan beliau, salah satunya adalah Nabi Ibrahim a.s adalah seorang sosok ayah yang berhasil dalam upaya membina keluarga sejahtera yang berhasil meraih sukses besar. Keberhasilan Nabi Ibrahim a.s membina keluarga bahagia sejahtera ditunjukkan oleh banyak indikator, diantaranya adalah bagaimana dia dapat menjadikan anak yang walaupun usianya masih muda, namun memiliki kematangan jiwa serta ketakwaan yang luar biasa jika dibandingkan dengan anak seusianya.

\footnotetext{
${ }^{2}$ http://jatim1.kemenag.go.id/file/dokumen/279jendelakeluarga.pdf. on line, 23 mei 2012

${ }_{3}^{3}$ Depag RI, al-Quran dan Terjemahannya, Bandung: Gema Risalah Press, edisi revisi, 1992. H. 923
} 
Salah satu ayat al-Quran yang menceritakan komunikasi Nabi Ibrahim as. dengan anaknya nabi Ismail as. adalah terdapat pada surah Ash-Shaffat ayat 102:

Artinya: "Maka tatkala anak itu sampai (pada umur sanggup) berusaha bersama-sama Ibrahim, Ibrahim berkata: "hai anakku sesungguhnya aku melihat dalam mimpi bahwa aku menyembelihmu. Maka pikirkanlah apa pendapatmu!" Ia menjawab: 'Hai bapakku, kerjakanlah apa yang diperintahkan kepadamu; insya Allah kamu akan mendapatiku termasuk orang-orang yang sabar." (Q. S. Ash shaffat [37]: 102) ${ }^{4}$

Ayat di atas sangatlah populer dan hampir selalu menjadi rujukan para khatib terutama pada saat khutbah shalat hari raya Idul Adha/Idul qurban. Ayat tersebut memberikan keteladanan tentang ketaatan kepada Allah, tawakkal dan kesabaran. Baik terhadap oleh orang yang sudah tua maupun yang masih belia. Kualitas kejiwaan, kematangan pribadi serta keimanan yang kuat nabi Ismail as. tentunya bukan datang secara tiba-tiba, ada proses yang membentuknya, dan dalam al-quran yang tergambar adalah cerita nabi Ibrahim as. dengan nabi Ismail as.

\section{STUDI TERHADAP Q.S., ASH SHAFFAT AYAT 100-102}

\section{Pengetian Kosa Kata}

Kata ( غلام ghulam adalah seorang pemuda yang telah tumbuh memanjang kumisnya. Biasanya, yang mencapai usia tersebut telah tumbuh pula nafsu seksualnya. Karena itu, nafsu seksual juga dinamai dengan (غلمة) ghulmah. ${ }^{5}$

Kata (حليم) halim terambil dari akar kata yang terdiri dari huruf ha, lam, dan mim yang mempunyai tiga makna dasar, yakni tidak tergesa-gesa, lubang karena kerusakan, serta mimpi.

Bagi manusia, ketidak tergesa-gesaan diantaranya dikarenakan memikirkan secara matang atas tindakan yang akan diperbuat. Dari sini, kata ini pun diartikan dengan akal pikiran dan antonim kejahilan. Bisa saja ketidaktergesa-gesaan lahir dari ketidaktahuan seseorang atau keraguannya. Ketika itu, ia tidak dapat dinamakan halim meskipun ia tidak tergesa-gesa. Bisa juga ia menunda sanksi karena ia tidak mampu, ini juga menggugurkan sifat tersebut darinya. Selanjutnya,penyandangnya pun harus dapat menempatkan setiap kasus yang dihadapinya pada tempat yang semestinya, antara lain mengetahui sampai batas mana setiap kasus ditangguhkan, dan ini mengharuskan ia bersikap hakim (bijaksana). ${ }^{6}$

Kata حليم dapat juga diartikan sangat penyabar. Perbedaan di antara sifat shabir (penyabar) dengan haliim adalah, bahwa hilm itu menjadi tabiat atau bawaan hidup. Sabar sebagai perisai menangkis gelisah ketika cobaan datang dengan tiba-tiba. Sedangkan haliim apabila kesabaran tersebut sudah menjadi sikap hidup, atau sikap jiwa. ${ }^{7}$

nafkah.

السعي suatu batas (umur) sanggup berusaha/ bekerja bersama ayahnya untuk mencari

${ }^{4}$ Ibid., h. 725

${ }^{5}$ M. Quraish Shihab, Tafsir al-Mishbah Pesan, Kesan, dan Keserasian Makna, Jakarta: Lentera hati, cet. Ke-2. 2009. H. 279

${ }^{6}$ Ibid., h. 279

${ }^{7}$ Hamka, Tafsir Al-azhar, Jakarta: Pustaka Panjimas, juzu' 23. 2002. h. 142

${ }^{8}$ Muhammad mahmud Hijazi, Tafsir al-Wadhih, Beirut: Daar al Jail, t.t. lihat juga Imam Ibn Katsir, Tafsir al-Quran al-'Adzim, beirut: Daar al Fikr, cet.1. 1980, h. 24 
2. Kandungan Ayat

A). Ayat 100

Ayat ini adalah sebuah pengharapan yang sangat kuat oleh Nabi Ibrahim a.s., kepada Allah dengan memohon kepada-Nya agar dianugerahi anak yang taat, yakni anak yang nantinya diharapkan dapat membantu pelaksanaan dakwah, menjadi hiburan/ menemani di tempat perantauan dan diharapkan menjadi penerus/ pengganti beliau kelak. ${ }^{9}$

B). Ayat 101

Ayat ini adalah jawaban pada ayat sebelumnya di mana nabi Ibrahim a.s. memohon dikarunia seorang anak, dan dijawab Allah dengan kabar gembira dengan bakal lahirnya seorang anak laki-laki yang ketika mencapai dewasa, dia menjadi anak yang sangat sabar.

Kedewasaan anak Ibrahim itu dapat dimengerti dari disifatinya dia sebagai seorang yang halim. Karena, sifat seperti itu memang lazim pada umur dewasa, disamping jarang sekali terdapat di kalangan anak-anak kecil sikap lapang dada, kesabaran yang baik dan ketidakliaran terhadap segala hal. Dan anak ini adalah Ismail as. Karena Ismail lah anak yang pertama-tama diberitakan kepada Ibrahim sebagai kabar gembira. Dia lebih besar dari Ishaq, demikian menurut kesepakatan para ulama, baik dari kalangan ahli kitab maupun kaum muslimin. Bahkan, ada sebuah nas dalam Taurat yang menyatakan bahwa Ismail dilahirkan ketika Ibrahim berumur 86 tahun. Sedang Ishaq lahir dikala beliau berumur 99 tahun. ${ }^{10}$

C). Ayat 102

Ketika anak yang dikaruniakan Allah kepada nabi Ibrahim menjadi pemuda. ${ }^{11}$ Diperintahkan oleh Allah untuk mnyembelihnya. Maka terjadilah dialog antara ayah dan anak berkenaan dengan mimpi bahwa beliau melihat menyembelih anaknya.

Takwil firman Allah : فانظر ماذا ترى (maka pikirkanlah apa pendapatmu!)

Para ahli qira'at berbeda pendapat dalam membaca lafazh ماذاذ ترى "Apa pendapatmu."

Mayoritas ahli qira'at Madinah dan Bashrah, serta sebagian ahli qira'at Kufah, membacanya dengan fathah pada huruf ta, yang artinya, apa yang engkau perintahkan, atau pikirkan apa yang kauperintahkan.

Jika ada yang bertanya, "Apakah Ibrahim berkompromi dengan anaknya dalam melaksanakan perintah Allah dan menaatinya?"

Jawabannya adalah, "Hal itu bukan musyawarah Ibrahim dengan anaknya dalam perkara taat kepada Allah, melainkan untuk mengetahui keteguhan pada diri anaknya, apakah ia sabar terhadap perintah Allah seperti dirinya sehingga ia

${ }^{9}$ Abi al- Fadhal Syihab al-Din al-Sayyid Mahmud al-Alusi al-Baghdadi, Ruhul Ma'ani, Beirut: Daar alFikr.t.t. H. 128.

${ }^{10}$ Ahmad Mustafa al-Maraghi, Tafsir al-Maraghi (terj), Semarang: CV Toha Putra Semarang, cet.ke-2, 1992. h. 125

11 Ada beberapa pendapat berkenaan umur yang dianggap mampu bekerja bersama ayahnya. Al-Farra berkata pada waktu itu ia (putranya) berumur tiga belas tahun. Al-qurthubi,234. Sedangkan Hamba dalam kitab tafsir al-azhar menyatakan usianya di antara 10-15 tahun. 
merasa gembira, ataukah tidak? Dalam kondisi apapun, Ibrahim tetap menjalankan perintah Allah. ${ }^{12}$

Ucapan sang anak: ( ستجدني إنشاءالله من الصابرين ) satajiduni insya Allah min min-ashbirin/engkau akan mendapatiku insya Allah termasuk para penyabar, dengan mengaitkan kesabarannya dengan kehendak Allah sambil menyebut terlebih dahuku kehendak-Nya, menunjukkan betapa tinggi akhlak dan sopan santun sang anak kepada Alllah swt. Tidak dapat diragukan lagi bahwa jauh sebelum peristiwa ini pastilah sang ayah telah menanamkan dalam hati dan benak anaknya tentang keesaan Allah dan sifat-sifat-Nya yang indah serta bagaimana seharusnya bersikap kepada-Nya. Sikap dan ucapan sang anak yang direkam oleh ayat ini adalah buah pendidikan tersebut. ${ }^{13}$

3. Munasabah Ayat

Dari munasabah ayat ini terlihat bahwa jalan dakwah pasti selalu menghadapi tantangan dan halangan, jika keadaan sangat tidak kondusif bagi seorang da'i dapat melakukan hijrah, namun tetap dengan niat meneruskan perjuangannya dan tidak pernah putus asa dan selalu berdo'a kepada Allah agar diberi kekuatan. Apa yang telah dilakukan dijalan Allah jika dilaksanakan dengan ikhlash pasti akan mendapat pertolongan serta ganjaran oleh Allah.

\section{Munasabah Surah}

Dari munasanabah surah terlihat adanya kaitan yang harmonis, di mana surah sesudahnya melengkapi dan menjelaskan surah sebelumnya, dengan tema yang sama, sehingga menimbulkan sebuah keyakinan yang teguh bahwa kebenaran akan menang, dan mereka yang berada di jalan kebenaran dan memperjuangkannya akan diberi pertolongan dan imbalan dari Allah baik di dunia maupun akhirat, dan orang yang menentang Allah akan hancur.

\section{KANDUNGAN Q.S. ASH SHAFFAT AYAT 100-102 TENTANG KOMUNIKASI ORANG TUA-ANAK}

Untuk membangun komunikasi yang baik antara orangtua-anak tidaklah mudah dan membutuhkan waktu yang lama. Berangkat dari paparan sebelumnya tafsiran QS ash-shaffat ayat 100-102, ada beberapa hal yang dapat diaplikasikan berkaitan dengan komunikasi orang tua-anak, yakni:

\section{A. Komunikasi yang dibangun oleh Nabi Ibrahim as. dengan anaknya ( Nabi Ismail} as.)

1. Membangun kebersamaan dan kepercayaan.

Pada QS ash-shaffat ayat 102 jelas diterangkan bagaimana nabi Ibrahim dan Nabi Ismail bekerjasama mencari nafkah. Gambaran tersebut menjelaskan bagaimana hubungan ayah dan anak sangat dekat, tidak mungkin seorang anak mendampingi orang tuanya bekerja mencari nafkah kalau belum terbangun kebersamaan yang

${ }^{12}$ Abu Ja'far Muhammad bin Jarir Ath-Thabari, Tafsir Ath-Thabari (terj), Jakarta: Pustaka Azzam, 2009. H. 887

${ }^{13}$ M. Quraish Shihab, Tafsir..., h. 280-281 
berlangsung lama dan saling percaya antara keduanya. Kedekatan fisik tentunya berpengaruh terhadap kedekatan hubungan, tidak terkecuali juga pada hubungan orangtua-anak. Contoh yang diteladankan oleh nabi Ibrahim dan nabi Ismail sangat relevan pada masa sekarang, orangtua perlu memperkenalkan sisi kehidupannya dan mengajak anaknya ikut berpartisipasi mengerjakan aktivitas kehidupan sehari-hari.

Untuk membangun kepercayaan antara orangtua-anak diperlukan usaha dan waktu yang panjang, seyogyanya orangtua sudah membangun kepercayaan anak sejak anak masih pada usia dini, kedekatan fisik dengan seringnya menjalin kebersamaan dalam kehidupan sehari-hari dapat mendatangkan rasa percara baik oleh orang tua kepada anaknya ataupun sebaliknya kepercayaan anak terhadap orang tuanya. Cara lainnya adalah dengan menunjukkan keselarasan percakapan dan perilaku terhadap anak, dan dilakukan secara terus-menerus, sehingga ketika anak menginjak remaja dia sudah memiliki kepercayaan yang tinggi terhadap orang tuanya. Perlunya keselarasan antara kata dan perbuatan sangatlah ditekankan, bahkan dalam al-Quran diberi penegasan bagaimana akibat yang akan diberikan bagi mereka yang tidak melaksanakan apa yang telah diucapkan pada Q.S., ash-Shaff ayat 2 dan 3 yang artinya:

"Hai orang-orang yang beriman, mengapa kamu mengatakan apa yang tidak kamu perbuat? Amat besar kebencian di sisi Allah bahwa kamu mengatakan apa-apa yang tiada kamu kerjakan". ${ }^{14}$

2. Menjalin komunikasi yang baik.

Hubungan yang terjalin baik antara orangtua-anak, berawal dari komunikasi yang dibangun antara orangtua-anak juga baik, dari Q.S., ashshaffat ayat 102 dapat dilihat bagaimana komunikasi yang dibangun oleh nabi Ibrahim kepada nabi Ismail, yaitu:

a. Komunikasi Dialogis

Pada Q.S., ashshaffat ayat 102 nabi Ibrahim berbicara dengan Nabi Ismail dengan teknik komunikasi dialogis, yakni adanya komunikasi dua arah antara orangtua-anak. Sebagaimana telah dibahas pada bab II bahwa ada berbagai tipe orang tua yang melakukan kesalahan dalam komunikasi dengan anak, tipe otoriter, tipe penceramah, tipe yang suka menyalahkan, dan tipe yang suka menggampangkan. Kesalahan tersebut terjadi karena orangtua menganggap bahwa mereka memiliki hak istimewa terhadap anaknya, sehingga sering memperlakukan mereka sesuai dengan keinginan mereka sendiri. Akan tetapi bila melihat bagaimana pembicaraan antara nabi Ibrahim dengan nabi Ismail sangat jelas bagaimana nabi ibrahim berbicara dengan bahasa yang sangat sopan kepada anaknya dan melakukan dialog/ menanyakan pendapat anaknya, padahal hal yang dibicarakan masalah yang berhubungan dengan keagamaan. Bisa saja beliau baik sebagai ayah dan sekaligus nabi-Nya memerintahkan kepada anaknya untuk menuruti apa yang disampaikan dan diperintahkan, apalagi nabi Ismail adalah sosok anak yang baik, namun hal tersebut tidak beliau lakukan. Hal ini

\footnotetext{
${ }^{14}$ Depag RI, Al-Qur'an..., h. 928
} 
menunjukkan kearifan dan kebijaksanaan orangtua dalam rangka menjalin komunikasi yang baik terhadap anaknya

b. Adanya keterbukaan

Pada ayat 102 juga terlihat bagaimana keterbukaan antara orangtua-anak yang terjalin. Nabi Ibrahim dengan nabi Ismail sama-sama membuka diri dalam menyampaikan informasi dan pendapat. Status orangtua dengan anak tidak menjadi penghalang bagi keduanya untuk dapat menyampaikan perasaan dan pendapat pribadi. Adanya keterbukaan antara dua belah pihak yang berkomunikasi memberi kontribusi yang besar bagi terciptanya hubungan antarpribadi yang baik. ${ }^{15}$

c. Empati dan sikap mendukung

Percakapan antara nabi Ibrahim dengan nabi Ismail mengisyratkan bahwa dalam komunikasi keduanya terdapat adanya empati (kemampuan seseorang untuk mengetahui apa yang sedang dialami orang lain suatu saat tertentu, dari sudut pandang orang lain, melalui kaca mata orang lain) ${ }^{16}$ dan sikap saling mendukung. Kedua sikap ini tentunya memiliki dampak positif dalam menyelesaikan permasalahan yang dihadapi dan akan mempererat sebuah hubungan, termasuk hubungan orang tua- anak.

\section{B. Urgensi yang terkandung dalam komunikasi yang dibangun Nabi Ibrahim as dengan anaknya Nabi Ismail as.}

1. Pentingnya Membangun Karakter komunikator dan Komunikan.

Pada kajian pustaka dikatakan bahwa karakteristik komunikasi yakni, Komunikasi adalah suatu proses; komunikasi adalah upaya yang disengaja dan memiliki tujuan ; Komunikasi menuntut adanya partisipasi dan kerjasama dari para pelaku yang terlibat; Komunikasi bersifat transaksional.

Melihat dari karakteristik tersebut, harus disadari untuk membangun komunikasi diperlukan kerjasama-kedua belah pihak, antara komunikator dan komunikan, karenanya bagaimana karakter komunikator maupun komunikannya dapat mempengaruhi hasil dari proses komunikasi itu sendiri.

Pada QS. Ash-shaffat ayat 100-102. Terlihat jelas karakter antara nabi Ibrahim a.s sebagai ayah (komunikator) dengan nabi Ismail a.s. sebagai anak (komunikan). Sebelum dikaruniai anak nabi Ibrahim a.s. sudah berdo'a dengan sungguh-sungguh agar anak yang nanti hadir di tengah mereka adalah anak yang shaleh. Kalau dilihat bagaimanakah karakter dari nabi Ibrahim sendiri? Dalam al-quran beliau dikatakan sebagai orang yang:

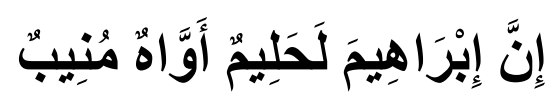

15 Kualitas keterbukaan mengacu pada sedikitnya tiga aspek dari komunikasi antarpribadi. Pertama, komunikator yang efektif harus terbuka kepada orang yang diajaknya berinteraksi.kedua, mengacu pada kesediaan komunikator untuk bereaksi secara jujur terhadap stimulus yang datang. Ketiga, menyangkut "kepemilikan" perasaan dan pikiran. Terbuka pada pengertian ini adalah mengakui bahwa perasaan dan pikiran yang dilontarkan adalah memang "miliki" anda dan anda bertanggungjawab atasnya. Lihat devito, Komunikasi..., h. 259-260.

${ }^{16}$ Ibid 
Artinya: "Sesungguhnya Ibrahim itu benar-benar seorang yang penyantun lagi penghiba dan suka kembali kepada Allah.” (QS. Huud [11]: 75) ${ }^{17}$

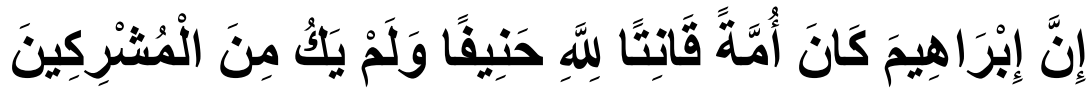

Artinya: "Sesungguhnya Ibrahim adalah seorang imam yang dapat dijadikan teladan lagi patuh kepada Allah dan hanif. Dan sekali-kali bukanlah dia termasuk orang-orang yang mempersekutukan (Tuhan).” ( QS. An-Nahl [16]: 120) ${ }^{18}$

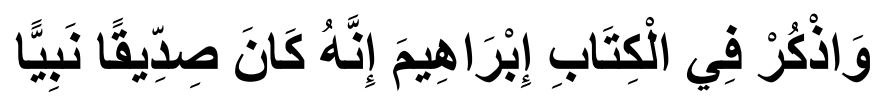

Artinya: "Ceritakanlah (hai Muhammad) kisah Ibrahim di dalam kitab (Al- Quran) ini. Sesungguhnya ia adalah seorang yang sangat membenarkan lagi seorang nabi." (QS maryam [19] : 41) ${ }^{19}$

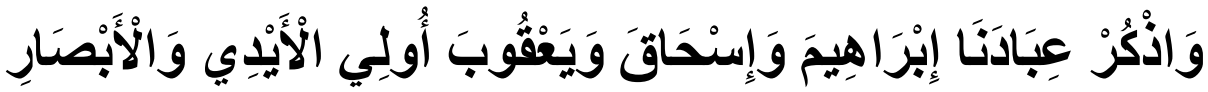

Artinya: "Dan ingatlah hamba-hamba Kami: Ibrahim, Ishaq dan Ya'qub yang mempunyai perbuatan-perbuatan yang benar dan ilmu-ilmu yang tinggi." (QS Shaad $[38]: 45)^{20}$

Dari beberapa ayat di atas, sangat jelas terlihat bagaimana kualitas diri nabi Ibrahim sebagai sosok orang tua, baik dari segi keilmuan, emosional dan spiritualnya, sehingga orang tua sudah seharusnya meningkatkan keilmuannya, mengasah kepekaan emosionalnya dan selalu meningkatkan kualitas spiritualnya. Dari orang tua yang luar biasa, merupakan modal untuk mendidik anak yang menjadi luar biasa pula, orang tua adalah sebagai contoh bagi anaknya, apa yang dilakukannya akan dilihat dan ditiru oleh anaknya. Hal tersebut dapat terlihat bagaimana al-quran menggambarkan sosok Nabi Ismail :

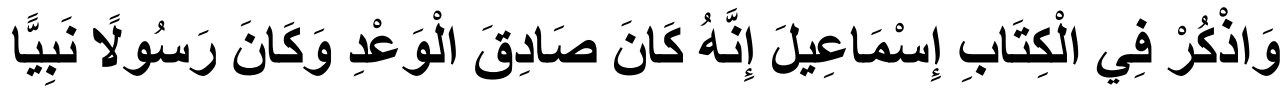

Artinya: “ Dan ceritakanlah (hai Muhammad kepada mereka) kisah Ismail ( yang tersebut ) di dalam al-quran. Sesungguhnya dia adalah seorang yang benar janjinya, dan dia adalah seorang rasul dan nabi." (QS. Maryam [19] : 54) ${ }^{21}$

\footnotetext{
${ }^{17}$ Depag RI, al-Quran..., h. 338

${ }^{18}$ Ibid., h.420

${ }^{19}$ Ibid., h.467

${ }^{20}$ Ibid., h. 738

${ }^{21}$ Ibid., h. 468
} 


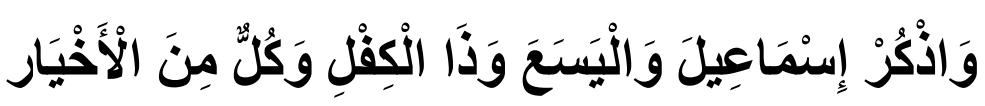

Artinya: “ dan ingatlah akan Ismail. Ilyasa' dan Zulkifli. Semuanya termasuk orangorang yang paling baik.” ( QS. Shaad [38] : 48) ${ }^{22}$

Dari kedua ayat di atas dan pada surah ash-shaffat sebelumnya, dapat tergambar bahwa nabi Ismail adalah sosok anak yang penyantun, sangat sabar, ikhlash menerima perintah Allah, dan taat kepada orang tuanya. Sosok seperti ini adalah cerminan anak yang sholeh sebagaimana anak yang diharapkan oleh nabi Ibrahim.

Ketika orang tua dan anak memiliki sama-sama memiliki karakter yang baik, dalam hal ini adalah orang tua dan anak yang sholeh, maka komunikasi yang terbangun adalah komunikasi yang menyejukkan, di mana ke dua belah pihak samasama saling menghargai dan menghormati, tanpa memaksakan kehendak, sehingga komunikasi berjalan efektif dan berhasil sesuai dengan tujuan yang diinginkan.

2. Pentingnya Pemilihan Bahasa dan Teknik Komunikasi yang Tepat

Dalam tataran praktis, ketika komunikasi berlangsung, pemilihan kata dan teknik penyampaian pesan yang tepat akan mempengaruhi bagaimana komunikasi akan berlangsung, yang pada akhirnya mempengaruhi hasil dari komunikasi itu sendiri.

Pada kisah nabi Ibrahim dengan Nabi Ismail, terlihat bagaimana nabi Ibrahim memanggil anaknya dengan lemah lembut (wahai anakku), kemudian di jawab dengan lembut pula oleh nabi Ismail dengan panggilan wahai ayahku. Kata yang lembut menjadikan komunikator dan komunikan merasa lebih dekat, sehingga lebih mudah memahami pesan yang diterima. Kata tersebut menyiratkan betapa dekat hubungan antar keduanya, tidak ada prasangka dan saling mempercayai, dan hal tersebut adalah modal yang kuat membangun sebuah hubungan yang baik, termasuk hubungan orang tua-anak. Dari terbinanya hubungan yang baik, maka komunikasi dapat berjalan dengan lancar, lebih efektif, dinamis dan berhasil sesuai harapan yang diinginkan.

Teknik komunikasi yang dibangun pada surah ash-shaffat ini adalah dialogis, di mana nabi Ibrahim meminta pendapat/ berdiskusi kepada nabi Ismail terhadap mimpi yang telah dia terima dari Allah. Sebagai orang tua apalagi yang disampaikan berhubungan dengan perintah Allah, bisa saja nabi Ibrahim menggunakan wewenangnya sebagai orang tua untuk langsung menyampaikan perintah Allah dan memerintahkan nabi Ismail untuk mentaatinya, namun hal tersebut tidak dilakukan.

Dari paparan di atas, maka dapat dilihat, bagaimana pemilihan kata yang baik serta bagaimana pendekatan/teknik komunikasi yang dibangun antara nabi Ibrahim dan nabi Ismail, membuahkan hasil yang luar biasa, yang dapat menjadi contoh teladan bagi setiap muslim di mana pun dan kapan pun.

\footnotetext{
${ }^{22}$ Ibid., h. 739
} 


\section{KESIMPULAN}

Dari paparan di atas maka dapat disimpulkan bahwa:

1. Komunikasi yang dibangun antara orang tua-anak (nabi Ibrahim a.s. dengan Nabi Ismail a.s. adalah : membangun kebersamaan dan kepercayaan; menjalin komunikasi yang baik melalui cara saling terbuka, melakukan dialog/diskusi dengan rasa saling menghargai dan menghormati; dapat berempati dan saling mendukung sehingga adanya kesamaan visi dalam melihat persoalan yang pada akhirnya tercipta komunikasi yang efektif. Kesamaan visi tersebut bersumber dari pemahaman agama yang benar dan sama -sama berusaha melaksanakan dan mengikhlashkannya.

2. Urgensi dari komunikasi yang dibangun antara orang tua-anak (nabi Ibrahim a.s. dengan Nabi Ismail a.s. adalah perlunya karakter yang kuat dari orang tua berdasarkan ajaran Islam sehingga anak yang dididiknya juga memiliki karakter yang baik pula. Jika orang tua-anak sama -sama orang yang shaleh tentunya komunikasi berjalan bukan untuk mencari siapa yang baik dan benar, namun komunikasi yang terbangun adalah karena keduanya sama-sama mencari ridha Allah dan selalu berdo'a agar diberi petunjuk dan kekuatan-Nya, sehingga ucapan, sikap dan tingkah laku merujuk pada ketentuan yang Allah berikan. Selain itu diperlukan pemilihan kata yang baik serta menggunakan teknik yang tepat.

\section{DAFTAR PUSTAKA}

al-'Aridl, 'Ali Hasan, Sejarah dan Metodologi Tafsir, Jakarta Pt RajaGrafindo Persada, 1994. cet.ke-2

al-Baghdadi, Abi al- fadhal Syihab al-Din al-Sayyid mahmud al-alusi, Ruhul Ma'ani, Beirut: Daar al-Fikr.t.t.

al-Farmawi, Abd al-Hay., al-Bidayah fii al-Tafsir al-Maudhu'i (Kairo: Maktabah alHadharrah,1977)

al-Maraghi, Ahmad Mustafa, Tafsir Al-Maraghi, Beirut: Daar al-Fikrh. H. 72. Lihat juga Syaikh Imam al- Qurthubi, Tafsir al- Qurthubi (terj). Jakarta: Pustaka Azzam, cet.ke1. 2009. h. 232.

-----, Tafsir al-Maraghi (terj), Semarang: CV Toha Putra Semarang, cet.ke-2, 1992.

Ath-Thabari, Abu Ja'far Muhammad bin Jarir, Tafsir Ath-Thabari (terj), Jakarta: Pustaka Azzam, 2009.

al Zain, Samîh Âthif, al Tafsîr al Maudhuî (Mujma' al Bayân al hadîts- tafsir mufradât al quran al Karîm), Beirut: Dâr al Kitâb al Banânî- maktabah al-madrasah, 1984, Cet. $\mathrm{Ke}-2$

Depag RI, al-Quran dan Terjemahannya, Bandung: Gema Risalah Press, edisi revisi, 1992.

Departemen Pendidikan dan Kebudayaan RI, Kamus Besar Bahasa Indonesia, Jakarta: Balai Pustaka, 1991.

Hamka, Tafsir Al-azhar, Jakarta: Pustaka Panjimas, juzu' 23. 2002.

Hijazi, Muhammad Mahmud, Tafsir al-Wadhih, Beirut: Daar al Jail, t.t. lihat juga Imam Ibn Katsir, Tafsir al-Quran al- 'Adzim, beirut: Daar al Fikr, cet.1. 1980.

Mulyana, Deddy, Ilmu Komunikasi Suatu Pengantar. (Bandung: PT Remaja Rosdakarya, 2000) cet. 1. 
------, Jalaluddin Rakhmat, M. Sc (editor), Komunikasi Antarbudaya, Bandung: PT Remaja Rosdakarya, 2003, Cet. ke-7

Moss, Stewart L. Tubbs-sylvia, Human Communication, Konteks-Konteks Komunikasi. Buku Pertama. Bandung: PT Remaja Rosdakarya, cet. ke-2. 2000

-----, Human Communication, Konteks-Konteks Komunikasi. Buku kedua. Bandung: PT Remaja Rosdakarya, cet. ke-2. 2000

Nasution, Zulkarnaen M.Sc., Perencanaan Program Komunikasi (Jakarta: Universitas Terbuka, 2001) Cet. ke-3.

Saefullah, Ujang M. Si, Kapita Selekta Komunikasi Pendekatan Budaya dan Agama, Bandung: Simbiosa Rekatama Media, cet. Ke-1. 2007

Syam Nina Winangsih, MS., Drs. Dadang Sugiana, M.Si., Perencanaan Pesan dan Media (Jakarta: Universitas Terbuka, 2001) Cet. Ke-1.

Sendjaja, Sasa Djuarsa Ph. D., dkk, Pengantar Komunikasi, Jakarta: Pusat Penerbitan Universitas Terbuka, 2001. Cet. Ke-6.

Shihab, M. Quraish, Membumikan al-Quran,Bandung:Mizan, 1993. cet.ke-3

-------, Tafsir al-Mishbah Pesan, Kesan, dan Keserasian Makna, Jakarta: Lentera hati, cet. Ke-2. 2009.

------- , (editor), Ensiklopedia Al-Quran: Kajian Kosakata, Jakarta: Lentera Hati, 2007.

Sobur, Alex, M. Si, Psikologi Umum, Bandung: Pustaka Setia, 2009, cet. Ke-2

Rakhmat, Jalaluddin, Psikologi Komunikasi, Bandung: PT Remaja Rosdakarya, 1992, Cet. $\mathrm{Ke}-7$

Ramayulis, Dr. H., Psikologi Agama, Jakarta: Kalam Mulia, cet. Ke-6, 2002. 